\title{
Primary squamous cell carcinoma of breast: A Rare Case Report
}

\author{
Haravi R.M. ${ }^{1}$, Bhandari B.J. ${ }^{2}$, Kittur S.K. ${ }^{3}$, Satihal S.N. ${ }^{4}$ \\ ${ }^{1}$ Dr Rekha M. Haravi, Associate Professor, ${ }^{2}$ Dr. Bhumika J. Bhandari, Post graduate, ${ }^{3}$ Dr Shreekant K. Kittur, \\ Professor and Head, ${ }^{4}$ Dr Sabu N. Satihal, Associate Professor, ${ }^{1,2,3}$ Department of Pathology, ${ }^{4}$ Department of Surgery, \\ Belagavi Institute of Medical Sciences, Belagavi, Karnataka, India
}

Address for Correspondence: Dr. Rekha M. Haravi, Associate Professor, Department of Pathology, Belagavi Institute of Medical Sciences, Dr. B.R. Ambedkar road, Belagavi, E-mail: drrekhagudli@yahoo.com

\begin{abstract}
Primary squamous cell carcinoma (SCC) of breast is a pure epithelial type of metaplastic carcinoma accounting for less than $0.1 \%$ of all breast cancers. A 70 year female presented with left breast lump of 4 months duration. Toilet mastectomy was done. Histopathology proved it to be primary SCC (large cell keratinizing) of breast. On immunohistochemistry, tumor cells were positive for pancytokeratin and epidermal growth factor receptor and negative for estrogen, progesterone receptors and HER-2/neu (triple negative). On follow up, after 1 month, patient presented with recurrence and metastasis to ipsilateral axillary lymph nodes. This case is presented for its rarity.
\end{abstract}

Keywords: Breast, Metaplastic, Squamous cell carcinoma, Triple negative

\section{Introduction}

Metaplastic carcinoma of breast accounts for less than $1 \%$ of all invasive mammary carcinomas [1]. Primary squamous cell carcinoma (SCC) of breast is a pure epithelial type of metaplastic carcinoma, accounting for less than $0.1 \%$ of all breast cancers $[1,2]$. These tumors are very aggressive, hormone receptor negative and hence generally thought to have poor prognosis [2]. We report a case of this rare breast malignancy in an elderly female with metastasis to ipsilateral axillary lymph nodes.

\section{Case History}

A 70 year old woman presented with lump in left breast of 4 months duration with an overlying ulcer of 15 days duration. On examination, lump measured $12 \times 10 \mathrm{cms}$, involving upper and lower medial quadrants, firm to soft in consistency, fixed to overlying skin and underlying structures. Overlying skin showed an ulcer which measured $1 \times 1 \mathrm{~cm}$. Nipple and areola were normal. On clinical examination, there was no palpable lump in right breast. Fine needle aspiration cytology (FNAC) was positive for malignant cells following which toilet mastectomy was performed. Grossly the mastectomy specimen measured $12 \times 10 \times 5 \mathrm{cms}$. Outer surface showed a diffuse nodular area which measured $6 \times 5 \mathrm{cms}$ and an ulcer which measured $1 \times 1 \mathrm{~cm}$. On cut surface, an ill-defined grey white mass was apparent which measured $7 \times 6 \mathrm{cms}$ with focal area of necrosis and cystic change (Figure 1a). On microscopy the overlying skin showed ulceration with normal adjacent squamous epithelium (Figure 1b). The grey white mass showed tumor cells arranged in large sheets, nests and trabeculae (Figure 1c). Large sheets of cells showed central area of necrosis. These cells were large, round to polygonal with large, vesicular nuclei, prominent nucleoli and abundant eosinophilic cytoplasm (Figure 1d). There was moderate nuclear pleomorphism. Many keratin pearls and frequent atypical mitotic figures (3-5/HPF) were seen. Stroma was fibrocollagenous and showed extensive areas of necrosis. There was no component of invasive ductal carcinoma or other types of metaplastic carcinomas. Immunohistochemistry (IHC) was performed. Tumor cells were positive for pancytokeratin and showed focal positivity for epidermal growth factor receptor (EGFR) and negative for estrogen receptor (ER), progesterone receptor (PR) and HER-2/neu (triple negative) (Figure 2). To exclude the possibility of metastatic SCC to breast, thorough clinical evaluation and relevant investigations were carried out. Final diagnosis of primary large cell keratinizing SCC of left breast was made.

Manuscript received: $05^{\text {th }}$ April 2017

Reviewed: $12^{\text {th }}$ April 2017

Author Corrected: $20^{\text {th }}$ April 2017

Accepted for Publication: $27^{\text {th }}$ April 2017 


\section{Case Report}

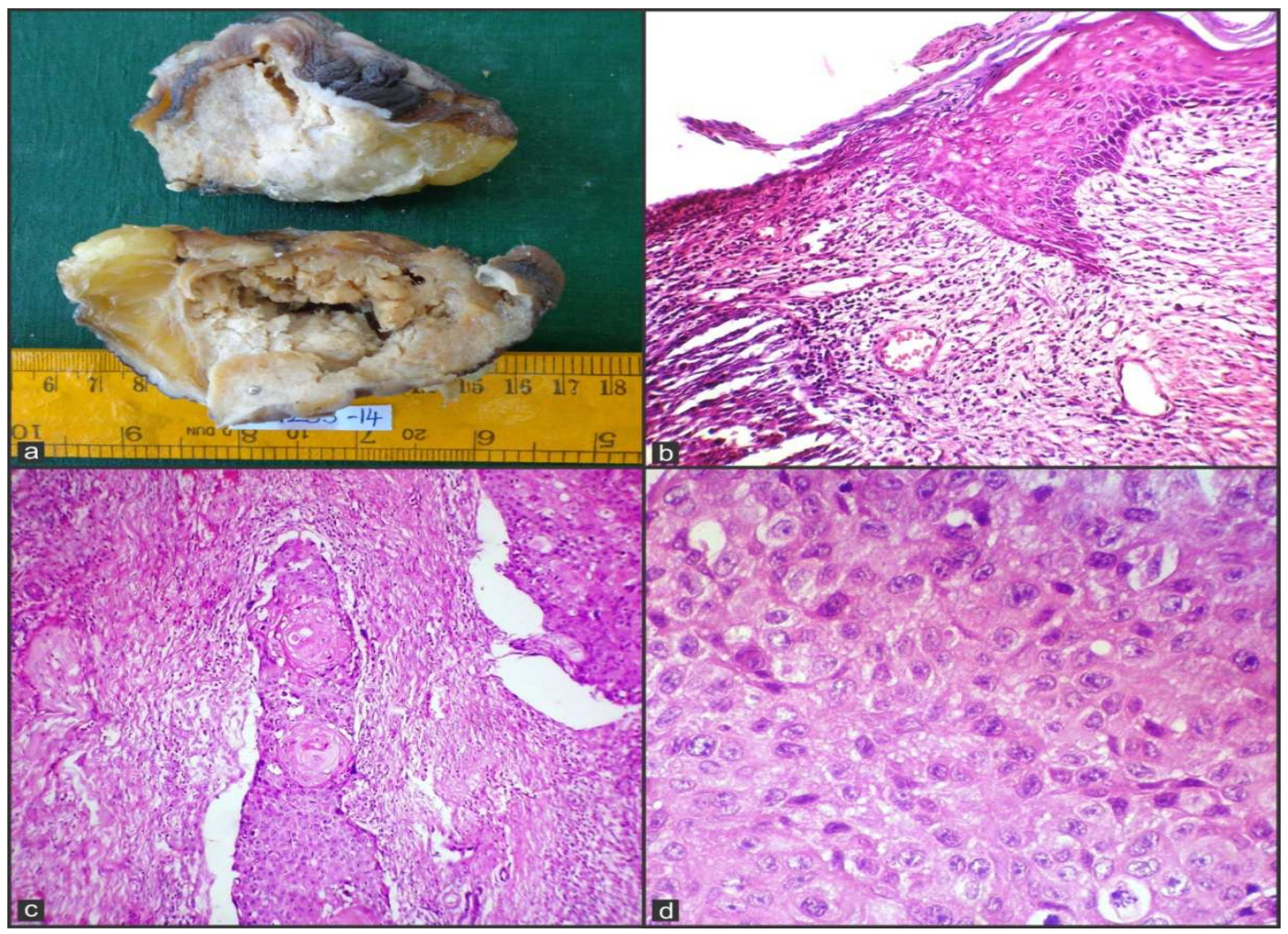

Figure- 1: a) Gross photograph showing tumor with central necrosis and irregular cystic area, b) Microphotograph showing surface ulceration and adjacent normal squamous epithelium ( $\mathrm{H}$ and $\mathrm{E}, \mathrm{x} 200)$, Microphotograph showing $\mathrm{c}$ ) arrangement (H and E, x100) and d) morphology of tumor cells ( $\mathrm{H}$ and E, x400).

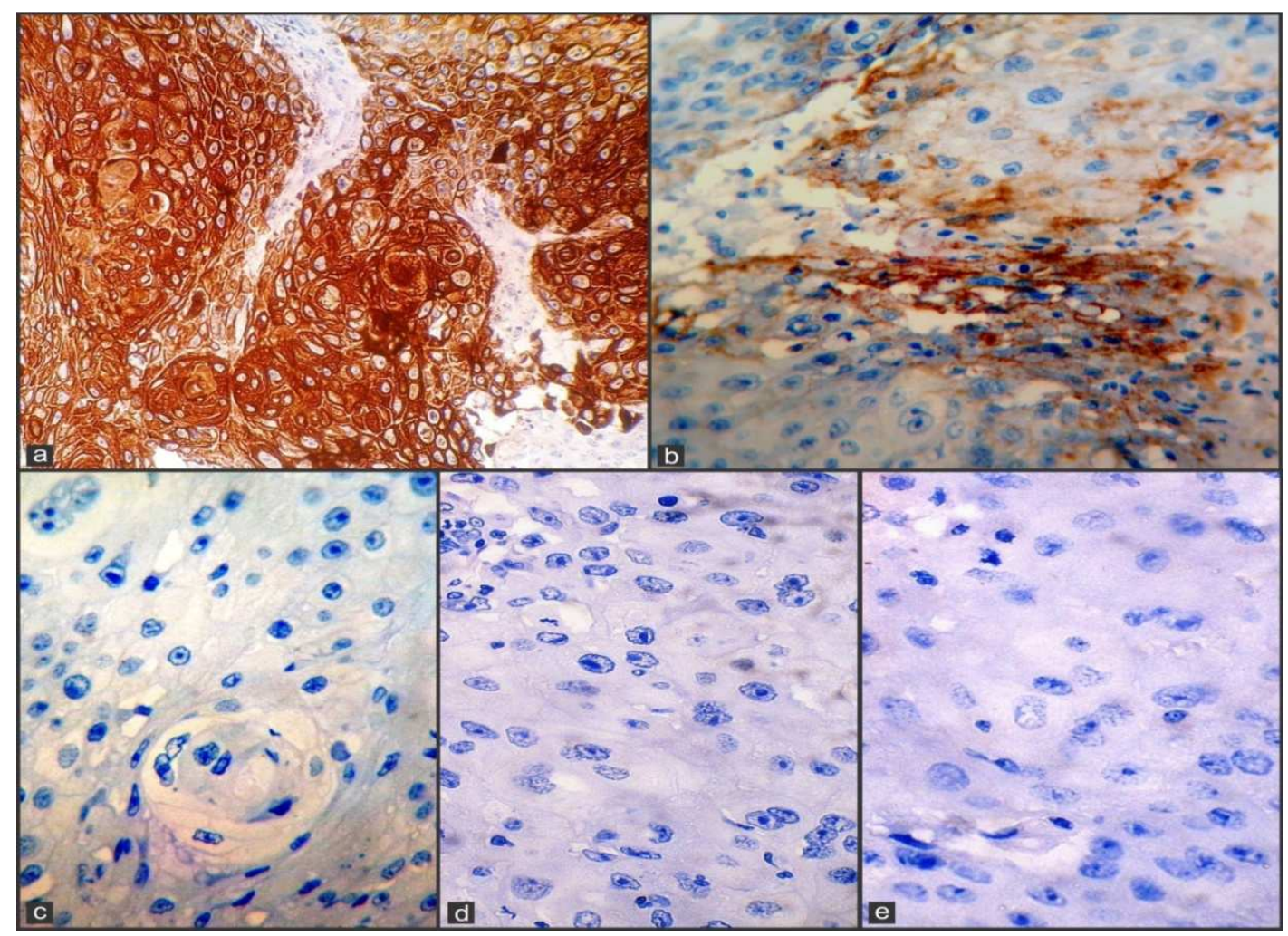

Figure 2: Microphotograph showing tumor cells a) positive for pancytokeratin (IHC, x400), b) focal positivity for EGFR (IHC, x400), c) ER negative (IHC, x400) d) PR negative (IHC, x400), e) HER-2/neu negative (IHC, x400). 
On follow up, after 1 month, patient presented with recurrence at the same site and with ipsilateral axillary lymphadenopathy, FNAC of which showed similar type of malignant cells in both sites.

\section{Discussion}

Primary SCC of breast is an extremely rare malignant neoplasm representing about $0.04 \%$ to $0.1 \%$ of all breast malignancies [3]. They are rapidly growing, large tumors $(>4 \mathrm{cms})$, usually diagnosed in an elderly women with a median age of 52 years [4]. Radiologically, no typical mammographic appearances are seen except for lack of microcalcifications. This metaplastic carcinoma of breast has an unclear histogenesis. Theories include malignant growth of intrinsic epidermal elements (epidermal or dermoid cysts) and metaplasia from breast parenchyma (benign disease like cystosarcoma phylloides, fibroadenomas or from breast malignancy like intraductal carcinoma) or from chronic abscess $[4,5]$.

Grossly, approximately $2 / 3^{\text {rd }}$ of these tumors are cystic or have a cystic component with central necrosis [5]. Microscopically, there are three subtypes of primary SCC of breast viz; large cell keratinizing, spindle cell and acantholytic type [1]. A tumor is called primary SCC of breast; when the malignant cells are all of squamous cell type, the origin of tumor is independent of the overlying skin and nipple and there is no other associated primary SCC at a second site in the body [4]. Also differential diagnosis must include other primary carcinoma in which squamous metaplasia are found [6].

The SCC of breast is usually a high grade and hormone receptor negative tumor. This means that hormone based therapy may not be effective in these tumors. HER-2/neu is also usually not over-expressed or amplified in this malignancy [7]. The only case of HER-2/neu over expression in SCC breast was reported by Karamouzis et al [8]. The high frequency of EGFR positivity is interesting and may be exploited in the development of future treatments [3]

SCC was found to be associated with a lower rate of lymph node metastasis at presentation compared to adenocarcinoma ( $22 \%$ vs. $40-60 \%$ for adenocarcinoma) [6]. In contrast, about $30 \%$ of the patients will develop distant metastasis [4,9]. Rate of local failure after surgery for such patients have been reported to be as high as 30\% [3]. The 5-year survival is $67 \%$ [9].

The prognosis of this type of breast cancer is still regarded as somewhat controversial, although many studies suggest that it is an aggressive disease that may behave like a poorly differentiated adenocarcinoma [7]. Because of its rarity, the most appropriate therapeutic regimen for SCC of the breast is still unclear [3]. Current surgical management is similar to that for adenocarcinoma. However because effective adjuvant or neoadjuvant therapy is not available, future research should focus on the molecular biology, (e.g. EGFR), to develop tumor-specific therapy [5].

\section{Conclusion}

Primary SCC of breast is rare, rapidly growing tumor. Due to locoregional spread, relapses and aggressive nature of SCC, prognosis and most appropriate treatment regimen is still controversial. This case is presented for its rarity.

\section{Acknowledgement: None}

Funding: Nil, Conflict of interest: None initiated, Permission from IRB: Yes

\section{References}

1. Ellis IO, Schitt SJ, Sastre-Garau X, Bussolati G, Tavassoli FA, Eusebi V, et al. Tumours of the breast. In: Tavassoli FA, Devilee P,editors. World Health Organization Classification of Tumours. Pathology and Genetics of Tumours of the Breast and Female Genital Organs. Lyon: IARC Press; 2003.p.9-112.

2. Vekariya M, Gupta V, Pednekar A, Nagur B, Mahna A, Patankar R. Primary squamous cell carcinoma of the breast: A rare case report. Int J Sci Stud 2014;2(8):2268.

3. Dasgupta S, Dasgupta J, Sarkar R. Primary Squamous Cell Carcinoma of Breast: A Case Report with Brief Review of Literature. Sch J Med Case Rep 2014; 2(7):457-60.

4. Flikweert ER, Hofstee M, Liem MS. Squamous cell carcinoma of the breast: a case report. World J Surg Oncol. 2008 Dec 21;6:135. doi: 10.1186/1477-7819-6135. 
5. Mitra B, Pal M, Debnath S, Paul B, Saha TN, Maiti A. Primary squamous cell carcinoma of breast with ipsilateral axillary lymph node metastasis: An unusual case. Int J Surg Case Rep. 2011;2(7):194-7. doi: 10.1016/j.ijscr.2011.06.006. Epub 2011 Jun 25.

6. Gursel B, Bayrak IK, Cakir S, Yildiz L, Gursel M, Yucel I. Primary squamous cell carcinoma of the breast: A case report and review of the literature. Turkish journal of cancer 2007;37(3):114-6.

7. Carbone S, Lobo Alvarez R, Lamacchia A, Almenar Gil A, Martin Hernandez R, Lopez Guerra JL, Marsiglia H. Primary squamous cell carcinoma of the breast: A rare case report. Rep Pract Oncol Radiother.
2012

Aug

9;17(6):363-6.

doi:

10.1016/j.rpor.2012.07.004. eCollection 2012.

8. Karamouzis MV, Fida A, Apostolikas N, Rigatos G. A case of HER-2(+) squamous cell breast carcinoma: an unusual presentation of an unusual clinical entity. Eur $\mathbf{J}$ Surg Oncol. 2006 Dec;32(10):1250-1. Epub 2006 Jun 21.

9. Bhosale SJ, Kshirsagar AY, Deshmukh SJ, Jagtap SV, Langade YB. Squamous cell carcinoma of the breast. Am J Case Rep 2013:14:188-90. doi:10.12659/AJCR.883934.

\section{How to cite this article?}

Haravi R.M., Bhandari B.J., Kittur S.K., Satihal S.N. Primary squamous cell carcinoma of breast: A Rare Case Report. Trop J Path Micro 2017;3(2):120-123.doi: 10.17511/jopm.2017.i2.07. 